\title{
Vaccines targeting the neovasculature of tumors
}

\author{
Vascular Cell 3:7 I DOI: 10.1186/2045-824X-3-7 I C Li et al.; licensee Publiverse Online S.R.L. 2011 \\ Received: 22 Nov 2010 | Accepted: 8 Nov 2011 | Published: 8 Nov 2011 \\ Matejuk Agata, Leng Qixin, Chou Szu-Ting, Mixson Archibald J ${ }^{@}$ \\ + Contributed equally ${ }^{@}$ Corresponding author
}

\begin{abstract}
Angiogenesis has a critical role in physiologic and disease processes. For the growth of tumors, angiogenesis must occur to carry sufficient nutrients to the tumor. In addition to growth, development of new blood vessels is necessary for invasion and metastases of the tumor. A number of strategies have been developed to inhibit tumor angiogenesis and further understanding of the interplay between tumors and angiogenesis should allow new approaches and advances in angiogenic therapy. One such promising angiogenic approach is to target and inhibit angiogenesis with vaccines. This review will discuss recent advances and future prospects in vaccines targeting aberrant angiogenesis of tumors. The strategies utilized by investigators have included whole endothelial cell vaccines as well as vaccines with defined targets on endothelial cells and pericytes of the developing tumor endothelium. To date, several promising anti-angiogenic vaccine strategies have demonstrated marked inhibition of tumor growth in pre-clinical trials with some showing no observed interference with physiologic angiogenic processes such as wound healing and fertility.
\end{abstract}

\section{Introduction}

Cancer mortality is related to the spread of neoplastic cells to distant loci where the cells, supported by existing blood vessels and angiogenesis, proliferate and give rise to secondary tumors. Tumor angiogenesis is up-regulated by a number of conditions including hypoxia, hypoglycemia, mechanical disruption, and genetic and inflammatory alterations [ 1] that lead to activation of growth factors and pro-angiogenic genes [ 2,3]. The stringent regulation of angiogenesis in normal tissues is often lacking in tumor angiogenesis, resulting in immature and leaky tumor vessels. Furthermore, compared to the tissue-vessel distribution in normal tissue, there is an uneven distribution of vessels within tumors, leading to tumor hypoxia and inefficient transport of chemotherapeutic drugs. In contrast to normal endothelial cells, in which the vast majority are quiescent, tumor endothelial cells actively proliferate, driven by hypoxia and increased levels of angiogenic factors and their cognate receptors. These differences between quiescent and angiogenic endothelial cells resulted in the first clinical anti-angiogenesis trial on human cancer two decades ago. There are now several anti-angiogenic therapies that have received FDA approval including sunitinib, sorafenib, and bevacizumab; and with more than 40 anti-angiogenic drugs in clinical trials [4], further advances are anticipated [ 5-11].

Differences among tumor endothelial cells and non-malignant endothelial cells may not only be quantitative but in some instances may also be qualitative. With serial analysis of gene expression, investigators compared gene expression from endothelial cells isolated from normal or malignant tissue, and found that several transcripts (e.g., CD276) were specifically elevated in the tumor endothelium [ 12,13]. Although most receptors/proteins that are increased in the tumor endothelium are also up-regulated in physiologic angiogenic processes, CD276 is not increased in the vessels of wounds or the corpus luteum [ 13]. Nevertheless, CD276 is not completely specific for the tumor endothelium because its expression may be induced by cytokines on the cell surfaces of B cells, $\mathrm{T}$ cells, and dendritic cells. There are also many proteins/receptors in tumor endothelial cells that are overexpressed (such as VEGFR2 and survivin) compared to expression in quiescent endothelial cells. Proteins differentially expressed on tumor endothelial cells or the supporting matrix are attractive targets for vaccine strategies, with the goal of breaking tolerance to self-antigens.

Targeting the tumor vasculature with vaccines as well as with other immunotherapies may have several potential advantages over targeting tumor cells. First, tumor endothelial cells are more accessible to the immune system than are tumor cells at a distance from the vessels. Second, endothelial cells of the tumor are usually more stable genetically than tumor cells, thereby reducing the risk of resistance developing to immunotherapies [ 14, 15]. Chromosomal abnormalities, however, have been identified in endothelial cells of solid tumors [ 16, 17], and in glioblastomas, the tumor cells and its endothelium are derived from common cancer stem-like cells [ 18, 19]. Third, down-regulation of MHC I in tumor cells occurs less frequently in tumor endothelial cells, thereby leading to a more potent CD8+-mediated response. Fourth, since inhibition of a single endothelial cell can inhibit up to 100 tumor cells [ 20,21], immunotherapies directed toward tumor endothelial cells have the potential of an amplifying inhibitory effect.

As a result of these putative advantages and differentially expressed proteins in the tumor endothelium, a number of immunotherapeutic strategies have targeted angiogenesis, including monoclonal antibodies, vaccinations, and adjuvant co- 
stimulatory therapies [ 1]. The most successful of these approaches, thus far, has been passive immunotherapy by utilizing monoclonal antibodies. In 2004, the monoclonal antibody bevacizumab which targets angiogenesis through VEGF received approval for treatment of colorectal cancer [ 22]. Bevacizumab has also shown efficacy against other cancers including lung, renal, and breast cancers [ 23, 24]. It is likely that the success and ability of bevacizumab to selectively target tumor endothelial cells has provided impetus to development of other forms of angiogenic immunotherapies. Several promising preclinical studies of tumor endothelial vaccines have led to clinical trials that are primarily in phase I. In the burgeoning field of tumor immunotherapies, we will focus on tumor vaccines that have a major anti-angiogenic component.

\section{Delivery Systems of Tumor Endothelial Vaccines}

As this review will highlight, there are many promising tumor endothelial vaccines with demonstrated efficacy in various animal models. These vaccines have been delivered by different approaches/vectors, including direct inoculation of peptides or "naked DNA", gene gun with gold particles, intradermal electroporation, tumor or dendritic cell-based vectors, and attenuated live bacteria vectors. The particular delivery system for anti-angiogenic vaccine therapy is selected at least in part based on whether immunizations are comprised of peptides/proteins, DNA, or RNA. For peptide delivery systems, the peptide can be inoculated directly into the animal model along with an adjuvant, or dendritic cells can be pulsed with the peptides before their inoculation. For gene therapy vaccine approaches, recombinant DNA may be delivered alone ("naked DNA"), by non-viral and viral carriers, or by eukaryotic and prokaryotic cells. Although delivery systems for vaccines targeting tumor endothelial cells generally mirror those targeting tumor cells [25-29], there are exceptions such as the infrequent use of viruses with tumor-endothelial vaccines. Nevertheless, we see no contraindication to using modified herpes simplex or vaccinia viruses to augment the immune response of endothelial vaccines as in tumor cell vaccines.

To date, plasmids encoding angiogenic self-antigens are the most common forms of nucleic acid to demonstrate an antiangiogenic effect in mouse models. Moreover, bacteria have been the most frequently used delivery system for plasmidbased vaccines (see reviews of [ 30, 31]). Of the 32 vaccines with specific targets covered in this review, bacteria were the primary delivery vector in 11 studies, whereas direct inoculation of "naked" plasmid DNA was the primary delivery system in 6 studies (see Table 1). Several animal studies have demonstrated that orally administered bacteria-based vectors with attenuated, nonreplicating strains of Listeria or Salmonella have the potential to prevent and treat cancer through inhibition of angiogenesis [ 32-35]. Although safety concerns are a factor in considering these bacterial delivery systems, it is of note that one Salmonella enterica strain has been approved by the FDA for vaccine use [ 30, 36]. Moreover, several bacteria-based vaccines that had marked anti-angiogenic and anti-tumor activity showed little to no autoimmune response, at least in the animal studies. Electroporation is also an appealing approach that has been used with DNA or RNA vaccines that target the tumor endothelium [ 37, 38]. Because of the high number of antigen presenting cells, the skin is a common route of delivery for varied delivery systems including electroporation. The intradermal DNA vaccination approach enables long-term immune protection against tumor angiogenesis and growth. Although electroporation has been used less frequently than direct inoculation of plasmid DNA, it may be more effective. For example, intradermal electroporation of "naked DNA" gave a much stronger anti-angiogenic and anti-tumor immune response to survivin compared to intramuscular DNA injection [ 37, 39, 40].

Table 1

Different Strategies Utilized With Tumor Endothelial Vaccines

\begin{tabular}{|c|c|c|c|c|c|c|}
\hline TARGET & $\begin{array}{c}\text { FORM OF } \\
\text { THE } \\
\text { VACCINE }\end{array}$ & TUMORS & Vector/Route & MECHANISMS & $\begin{array}{c}\text { Other } \\
\text { Comments }\end{array}$ & REFERENCE \\
\hline \multicolumn{7}{|c|}{ Endothelial Cell Targets } \\
\hline \multirow[t]{3}{*}{ VEGFR2 } & $\begin{array}{l}\text { mVEGFR2-AP } \\
\text { fusion protein }\end{array}$ & $\begin{array}{c}\text { Melanoma } \\
\text { and lung } \\
\text { carcinoma }\end{array}$ & DC pulsed & $\begin{array}{c}\mathrm{Ab}, \mathrm{CTL} \\
\text { Primarily CD8+ }\end{array}$ & $\mathrm{P}$ & $\begin{array}{c}\text { Li Y et al., } 200 \\
{[45]}\end{array}$ \\
\hline & $\begin{array}{l}\text { Autologous } \\
\text { DNA vaccine- } \\
\text { full-length } \\
\text { mVEGFR2 }\end{array}$ & $\begin{array}{l}\text { Melanoma, } \\
\text { colon } \\
\text { carcinoma, } \\
\text { non-small cell } \\
\text { lung } \\
\text { carcinoma, } \\
\text { hepatoma }\end{array}$ & $\begin{array}{l}\text { S.typhimurium } \\
\quad, \text { oral }\end{array}$ & CTL & $\begin{array}{l}\text { Modest delay } \\
\text { in wound } \\
\text { healing P, T }\end{array}$ & $\begin{array}{c}\text { Niethammer A } \\
\text { et al., 2002 [ } \\
59]\end{array}$ \\
\hline & $\begin{array}{l}\text { Xenogeneic } \\
\text { DNA vaccine }\end{array}$ & $\begin{array}{c}\text { Murine } \\
\text { melanoma, } \\
\text { carcinoma, } \\
\text { fibrosarcoma, } \\
\text { lyphoma }\end{array}$ & $\begin{array}{l}\text { "Naked" DNA, } \\
\text { SC }\end{array}$ & $\begin{array}{l}\text { Ab, CTL, CD4+ } \\
\text { (Th1)-mediated }\end{array}$ & $\begin{array}{l}\text { Quail VEGFR2 } \\
\text { vaccine } \\
\text { Increased } \\
\text { levels of IgG2a } \\
\text { and } 2 \mathrm{~b} \mathrm{P}, \mathrm{T}\end{array}$ & $\begin{array}{c}\text { Liu, J-Y et al. } \\
2003 \text { [ 130] }\end{array}$ \\
\hline
\end{tabular}




\begin{tabular}{|c|c|c|c|c|c|c|}
\hline TARGET & $\begin{array}{c}\text { FORM OF } \\
\text { THE } \\
\text { VACCINE }\end{array}$ & TUMORS & Vector/Route & MECHANISMS & $\begin{array}{c}\text { Other } \\
\text { Comments }\end{array}$ & REFERENCE \\
\hline \multicolumn{7}{|c|}{ Endothelial Cell Targets } \\
\hline & $\begin{array}{l}\text { Autologous } \\
\text { DNA vaccine- } \\
\text { mVEGFR2 } \\
\text { fragment }\end{array}$ & $\begin{array}{l}\text { Breast tumor- } \\
\text { rat Her2 } \\
\text { expressing } \\
\text { carcinoma; } \\
\text { murine p53- } \\
\text { deficient } \\
\text { breast } \\
\text { carcinoma }\end{array}$ & $\begin{array}{c}L . \\
\text { monocytogenes } \\
\text {, oral }\end{array}$ & $\begin{array}{l}\text { CD8+ mediated } \\
\text { Inf- } \gamma \text { Elispot }\end{array}$ & $\begin{array}{c}\text { Encodes } \\
\text { listerolysin- } \\
\text { VEGFR2 } \\
\text { fragment; No } \\
\text { effect on } \\
\text { wound healing } \\
\text { or pregnancy P, } \\
\text { T }\end{array}$ & $\begin{array}{l}\text { Seavey MM e } \\
\text { al., } 2009 \text { [ } 32\end{array}$ \\
\hline & $\begin{array}{c}\text { Autologous } \\
\text { DNA minigene }\end{array}$ & $\begin{array}{l}\text { Murine breast } \\
\text { and colon } \\
\text { carcinomas }\end{array}$ & $\begin{array}{l}\text { S. typhimurium } \\
\text {, oral }\end{array}$ & CTL & $\begin{array}{l}\text { Encodes H- } \\
\text { 2Kd or H-2Dd } \\
\text { restricted } \\
\text { peptides P }\end{array}$ & $\begin{array}{l}\text { Luo Y et al., } \\
2007 \text { [ 63] }\end{array}$ \\
\hline & $\begin{array}{c}\text { Autologous } \\
\text { DNA minigene }\end{array}$ & $\begin{array}{l}\text { Murine lung, } \\
\text { prostate, and } \\
\text { breast cancers }\end{array}$ & $\begin{array}{l}\text { S. typhimurium } \\
\text {, oral }\end{array}$ & CTL & $\begin{array}{l}\text { Plasmid also } \\
\text { encodes HIV- } \\
\text { TAT peptide P }\end{array}$ & $\begin{array}{l}\text { Zhou H et al. } \\
2005 \text { [ 61] }\end{array}$ \\
\hline & $\begin{array}{l}\mathrm{H}-2 \mathrm{D}^{\mathrm{b}}- \\
\text { restricted } \\
\text { Peptides }\end{array}$ & $\begin{array}{l}\text { Murine colon } \\
\text { carcinomas }\end{array}$ & $\mathrm{SC}$ & CTL & $\begin{array}{c}\text { adjuvant (GM- } \\
\text { CSF, CD40 } \\
\text { Ab); T }\end{array}$ & $\begin{array}{c}\text { Dong Y et al. } \\
2006 \text { [ 62] }\end{array}$ \\
\hline & $\begin{array}{c}\text { HLA-A2 or-A24 } \\
\text { restricted } \\
\text { hVEGFR2 } \\
\text { Peptides }\end{array}$ & $\begin{array}{c}\text { Mouse } \\
\text { melanoma } \\
\text { and colon } \\
\text { carcinomas }\end{array}$ & ID & CTL & $\begin{array}{c}\text { HLA-24 } \\
\text { restricted } \\
\text { Peptide 169 } \\
\text { (RFVPDGNRI) } \\
\text { induced human } \\
\text { PBMC-CTL } \\
\text { lysis of } \\
\text { endothelial } \\
\text { cells }\end{array}$ & $\begin{array}{l}\text { Wada S et al. } \\
2005 \text { [ 43] }\end{array}$ \\
\hline & $\begin{array}{c}\text { VEGFR2 } \\
\text { Peptide } 169+ \\
\text { gemcitabine }\end{array}$ & $\begin{array}{c}\text { Pancreatic } \\
\text { cancer (Phase } \\
\text { I) }\end{array}$ & $\mathrm{SC}$ & $\begin{array}{l}\text { CTL; Reduced } \\
\text { Treg cells }\end{array}$ & Adjuvant (IFA) & $\begin{array}{l}\text { Miyazawa M. } \\
\text { al., } 2009 \text { [ } 66\end{array}$ \\
\hline & $\begin{array}{l}\text { Xenogeneic } \\
\text { DNA vaccine }\end{array}$ & $\begin{array}{l}\text { Murine breast } \\
\text { and colon } \\
\text { carcinoma }\end{array}$ & $\begin{array}{c}\text { Cationic } \\
\text { liposomes, IV }\end{array}$ & $\mathrm{Ab}, \mathrm{CTL}$ & $\begin{array}{c}\text { Human } \\
\text { VEGFR2; P, T }\end{array}$ & $\begin{array}{l}\text { Xie K et al., } \\
2009 \text { [ 65] }\end{array}$ \\
\hline & $\begin{array}{c}\text { Autologous } \\
\text { DNA vaccine } \\
\text { (VEGFR2 fused } \\
\text { with } \beta \text {-defensin } \\
\text { 2) }\end{array}$ & $\begin{array}{l}\text { Murine lung } \\
\text { and colon } \\
\text { cancer }\end{array}$ & $\begin{array}{c}\text { Cationic } \\
\text { liposomes, IM }\end{array}$ & $\mathrm{Ab}, \mathrm{CTL}$ & $\begin{array}{l}\text { Antitumor and } \\
\text { anti-angiogenic } \\
\text { synergy } \\
\text { between } \\
\text { VEGFR2 and } \\
\beta \text {-defensin-2; } \mathrm{P} \text {, } \\
\mathrm{T}\end{array}$ & $\begin{array}{l}\text { Wang YS et al } \\
2007 \text { [ 64] }\end{array}$ \\
\hline & $\begin{array}{l}\text { Autologous } \\
\text { DNA vaccine- } \\
\text { Extracellular } \\
\text { Domain }\end{array}$ & Murine Lung & $\begin{array}{l}\text { S. typhimurium } \\
\text {, oral }\end{array}$ & $\begin{array}{l}\mathrm{Ab}, \mathrm{CTL} \text { CD4+ } \\
(\mathrm{Th} 1), \mathrm{C} 8+ \\
\text { mediated }\end{array}$ & $\begin{array}{l}\text { Increased } \\
\text { levels of IgG2a } \\
\text { and } 2 \mathrm{~b} \mathrm{P}\end{array}$ & $\begin{array}{c}\text { Zuo SG et al. } \\
2010 \text { [ 67] }\end{array}$ \\
\hline VEGF & $\begin{array}{l}\text { Xenogeneic } \\
\text { DNA vaccine }\end{array}$ & $\begin{array}{l}\text { Fibrosarcoma, } \\
\text { breast cancer, } \\
\text { hepatoma }\end{array}$ & $\begin{array}{l}\text { "Naked" DNA, } \\
\text { IM }\end{array}$ & $\begin{array}{c}\text { Ab CD4+- } \\
\text { mediated }\end{array}$ & $\begin{array}{c}\text { Xenopus } \\
\text { VEGF has } \\
\text { about } 75 \% \\
\text { homology with } \\
\text { humans and } \\
\text { mice P, T }\end{array}$ & $\begin{array}{c}\text { Wei YQ et al. } \\
2001[58]\end{array}$ \\
\hline & $\begin{array}{l}\text { Autologous or } \\
\text { xenogeneic } \\
\text { protein }\end{array}$ & $\begin{array}{l}\text { Murine and } \\
\text { human colon } \\
\text { caricinoma; } \\
\text { human } \\
\text { rhadosarcoma }\end{array}$ & IM & $\mathrm{Ab}$ & $\begin{array}{l}\text { h- or mVEGF } \\
\text { conjugated to } \\
\text { KLH P }\end{array}$ & $\begin{array}{c}\text { Rad FH et al. } \\
2007 \text { [ 73] }\end{array}$ \\
\hline FGFR-1/bFGF & $\begin{array}{l}\text { Autologous } \\
\text { bFGF peptide }\end{array}$ & $\begin{array}{l}\text { Murine } \\
\text { melanoma } \\
\text { and lung } \\
\text { carcinoma }\end{array}$ & $\begin{array}{c}\text { Lipid A } \\
\text { containing } \\
\text { liposomes IM }\end{array}$ & $\mathrm{Ab}$ & $\begin{array}{l}\text { Effective } \\
\text { vaccine against } \\
\text { the } 44 \text { aa } \\
\text { segment of the } \\
\text { heparin binding } \\
\text { domain; No } \\
\text { effect on } \\
\text { wound healing } \\
\text { or pregancy P }\end{array}$ & $\begin{array}{c}\text { Plum SM et al } \\
2000 \text { [ 76] Plu } \\
\text { SM et al., } 200 \\
{[77]}\end{array}$ \\
\hline
\end{tabular}




\begin{tabular}{|c|c|c|c|c|c|c|}
\hline TARGET & $\begin{array}{c}\text { FORM OF } \\
\text { THE } \\
\text { VACCINE }\end{array}$ & TUMORS & Vector/Route & MECHANISMS & $\begin{array}{c}\text { Other } \\
\text { Comments }\end{array}$ & REFERENCF \\
\hline \multicolumn{7}{|c|}{ Endothelial Cell Targets } \\
\hline \multirow{3}{*}{ TEM8 } & $\begin{array}{l}\text { Xenogeneic } \\
\text { DNA vaccine }\end{array}$ & $\begin{array}{l}\text { Murine } \\
\text { fibrosarcoma, } \\
\text { hepatoma and } \\
\text { breast cancer }\end{array}$ & $\begin{array}{l}\text { "Naked" DNA, } \\
\text { IM }\end{array}$ & $\mathrm{Ab}$ & $\begin{array}{l}\text { FGFR-1 from } \\
\text { Xenopus laevis } \\
\text { Delayed wound } \\
\text { healing P, T }\end{array}$ & $\begin{array}{c}\text { He QM et al. } \\
2003[78]\end{array}$ \\
\hline & $\begin{array}{l}\text { Autologous } \\
\text { TEM8 with rat } \\
\text { Her2 or human } \\
\text { tyrosinase- } \\
\text { related protein } 1 \\
\text { DNA vaccine }\end{array}$ & $\begin{array}{l}\text { Rat Her-2 } \\
\text { expressing } \\
\text { breast } \\
\text { carcinoma; } \\
\text { Murine } \\
\text { melanoma }\end{array}$ & $\begin{array}{l}\text { Gold-particle } \\
\text { gene gun }\end{array}$ & $\begin{array}{c}\text { No } \mathrm{Ab} \text { or CTL } \\
\text { response with } \\
\text { TEM8 vaccine } \\
\text { alone }\end{array}$ & $\begin{array}{c}\text { Synergy } \\
\text { observed P }\end{array}$ & $\begin{array}{c}\text { Felicetti P et a } \\
2007 \text { [ 82] }\end{array}$ \\
\hline & $\begin{array}{l}\text { Xenogeneic } \\
\text { DNA vaccine }\end{array}$ & $\begin{array}{l}\text { Murine } \\
\text { melanoma }\end{array}$ & $\begin{array}{l}\text { S.typhimurium } \\
\text { oral }\end{array}$ & CTL; & $\begin{array}{c}\text { Human TEM8 } \\
\text { No effect on } \\
\text { wound healing } \\
\mathrm{T}\end{array}$ & $\begin{array}{c}\text { Ruan Z et al. } \\
2009 \text { [ 83] }\end{array}$ \\
\hline $\begin{array}{l}\text { ENDOGLIN } \\
\quad(\text { CD105) }\end{array}$ & $\begin{array}{l}\text { Xenogeneic } \\
\text { protein }\end{array}$ & $\begin{array}{l}\text { Murine lung, } \\
\text { melanoma, } \\
\text { colon } \\
\text { carcinoma, } \\
\text { fibrosarcoma }\end{array}$ & $\mathrm{SC}$ & $\mathrm{Ab}$ & $\begin{array}{l}\text { Synergy with } \\
\text { cis-platinum; } \\
\text { adjuvant } \\
\text { (alum) P, T }\end{array}$ & $\begin{array}{c}\text { Tan GH et al. } \\
2004 \text { [ 87] Ta } \\
\text { GH et al., } 200 \\
\text { [ } 88]\end{array}$ \\
\hline ANGIOMOTIN & $\begin{array}{l}\text { Xenogeneic } \\
\text { DNA vaccine, } \\
\text { full-length }\end{array}$ & $\begin{array}{l}\text { Her-2 } \\
\text { expressing } \\
\text { breast cancer } \\
\text { in transgenic } \\
\text { mice }\end{array}$ & $\begin{array}{c}\text { Electroporation, } \\
\text { TC }\end{array}$ & $\mathrm{Ab}$ & $\begin{array}{l}\text { Human angio- } \\
\text { motin and Her- } \\
2 \text {; antitumor } \\
\text { synergy when } \\
\text { combined with } \\
\text { Her-2 DNA } \\
\text { vaccine }\end{array}$ & $\begin{array}{l}\text { Holmgren L e } \\
\text { al., } 2006 \text { [ } 38\end{array}$ \\
\hline TIE2 & $\begin{array}{c}\text { Xenogeneic } \\
\text { protein vaccine }\end{array}$ & $\begin{array}{c}\text { Murine } \\
\text { hepatomas } \\
\text { and } \\
\text { melanomas }\end{array}$ & $\mathrm{SC}$ & $\mathrm{Ab}$ & $\begin{array}{c}\text { Chicken Tie2 P, } \\
\text { T }\end{array}$ & $\begin{array}{c}\text { Luo Y et al., } \\
2006 \text { [ 94] }\end{array}$ \\
\hline & $\begin{array}{l}\text { DNA vaccine } \\
\text { encoding HLA- } \\
\text { restricted } \\
\text { peptides }\end{array}$ & $\begin{array}{l}\text { In vitro lysis } \\
\text { of endothelial } \\
\text { cells } \\
\text { expressing } \\
\text { Tie-2; Tumor } \\
\text { response not } \\
\text { tested }\end{array}$ & $\begin{array}{l}\text { Gold-particle } \\
\text { gene gun }\end{array}$ & CTL & $\begin{array}{c}\text { HLA- } \\
\text { A*0201/Kb } \\
\text { transgenic } \\
\text { mice; the } \\
\text { epitope } \\
\text { (FLPATLTMV) } \\
\text { had the highest } \\
\text { CTL response; }\end{array}$ & $\begin{array}{l}\text { Ramage JM e } \\
\text { al., } 2004 \text { [ } 95\end{array}$ \\
\hline HP59/SP55 & $\begin{array}{l}\text { Xenogeneic } \\
\text { peptides }\end{array}$ & $\begin{array}{l}\text { Murine lung } \\
\text { carcinoma }\end{array}$ & Not stated & $\mathrm{Ab}$ & $\begin{array}{l}\text { HP59 and SP55 } \\
\text { peptide mixture } \\
\text { P }\end{array}$ & $\begin{array}{c}\text { Fu C et al., 20( } \\
\text { [96] }\end{array}$ \\
\hline
\end{tabular}

Pericyte Targets

\begin{tabular}{c|c|c|c|} 
& Murine & \\
Henogeneic & $\begin{array}{c}\text { melanoma, } \\
\text { renal }\end{array}$ & $L$ \\
DNA vaccine, & carcinoma, & monocytogenes \\
HMW-MAA & Her-2 & IP \\
fragment & transgenic & mice \\
PDGFR $\beta$ & $\begin{array}{c}\text { Autologous } \\
\text { DNA vaccine, } \\
\text { full-length }\end{array}$ & $\begin{array}{c}\text { Murine colon, } \\
\text { breast, lung } \\
\text { carcinoma }\end{array}$ & $\begin{array}{c}\text { S.typhimurium } \\
\text { oral }\end{array}$
\end{tabular}

$\mathrm{Ab}, \mathrm{CTL}$

HMW-MAA

(2160-2225 aa)

fragment fused to LLO T

Maciag PC e1 al., 2008 [ 33

Combined Targets

\begin{tabular}{c|c|c|c|} 
SURVIVIN & $\begin{array}{c}\text { Xenogeneic } \\
\text { DNA vaccine }\end{array}$ & $\begin{array}{c}\text { Murine } \\
\text { melanoma }\end{array}$ & $\begin{array}{c}\text { Electroporation, } \\
\text { ID }\end{array}$ \\
$\begin{array}{c}\text { Survivin/CCL21 } \\
\text { DNA vaccine }\end{array}$ & $\begin{array}{c}\text { Murine lung } \\
\text { carcinoma }\end{array}$ & $\begin{array}{c}\text { S.typhimurium } \\
\text {, oral }\end{array}$
\end{tabular}

CTL

CTL

Lladser A et a] 2010 [37]

Xiang R et al. 2005 [ 35] 


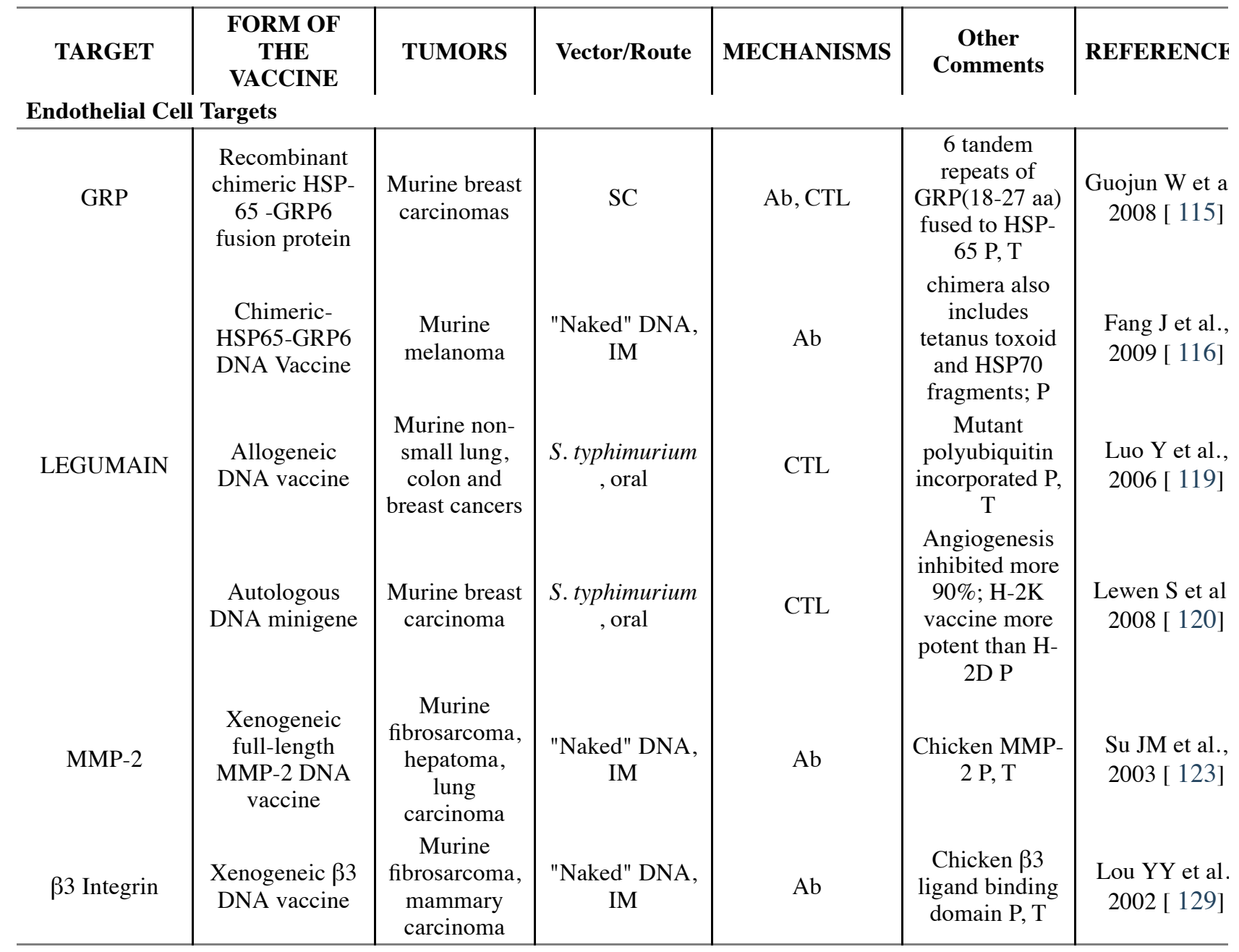

Abbreviations in table; Ab, antibody response; AP-alkaline phosphatase; CTL, cytotoxic T-lymphocyte response; m, mouse; h, Human; LLO, listerolysin; P, protective vaccine approach in which pre-immunized mice show anti-tumor activity; T, therapeutic vaccine approach in which vaccine, administered after tumor inoculation, has anti-tumor efficacy; keyhole limpet hemocyanin; SC, subcutaneous, ID, intradermal, IM, intramuscular, TC, transcutaneous

Besides tumor cells [ 41], dendritic cells (DC) pulsed with peptide/protein epitopes (or DNA encoding these epitopes) have also been employed successfully to vaccinate animals against tumor endothelial antigens [ 42, 43]. DC process and present antigens to T and B cells and produce cytokines and chemokines which in turn activate NK cells [ 44]. DC-based therapies involve modification with pulsed (loaded) defined peptides, whole protein lysate, and/or transfected DNA or RNA [ 42, 43]. An interesting anti-cancer and anti-angiogenic approach was the use of a VEGFR2-loaded DCs that led to greater than $80 \%$ reduction in lung metastases of two different tumor models [ 45]. Different forms of nucleic acids have also been used for angiogenic peptides and proteins. In addition to peptides, proteins, and recombinant DNA, mRNA is another promising strategy to enhance cellular immunity [ 46]. For example, antitumor synergy was observed when dendritic cells were transfected with mRNA from two receptors (VEGFR-2 and Tie2) that are highly expressed on tumor endothelial cells [ 47]. Varying the routes of pulsed DC administration may also affect the efficacy of tumor vaccines. Pellegatta and colleagues determined that glioblastomas regressed significantly more when mice received both intratumoral and subcutaneous pulsed DC injections compared to those which received subcutaneous injections [ 48].

Although most authors have not compared different carrier systems with one another, it is evident that the carrier system and route of administration are critical for the success of the vaccine in animal models and in human clinical trials [49]. We have already discussed differences in the immune response to survivin based on whether electroporation or direct injection of DNA was used. In addition, when Lai et al. compared three different delivery approaches (gene gun with noncoated particles, gene gun with coated gold particles, and intramuscular injection) for the EGFR plasmid vaccine, the genegun with non-coated particle vaccine had the greatest cytotoxic T-lymphocyte (CTL) response and anti-tumor response [ 49]. Interestingly, the CD4+ response and the levels of EGFR-specific antibodies were much greater with the coated gold particle method. The required robust immune response to overcome self-tolerance will no doubt eliminate several carriers, and perhaps autoimmunity will eliminate other carriers. Which of the carriers can be translated successfully from the animal models to humans remains to be determined. The delivery vehicle and the immune-adjuvant will likely be as important as the selected angiogenic antigen to obtain a successful tumor response in humans.

\section{Approaches for Anti-Angiogenic Vaccines}

A goal of vaccination in anti-angiogenic therapies targeting tumors is to break immune tolerance to self-antigens and induce specific, strong, and persisting immune response leading to eradication of cancer. Complex networks created by 
several immune-competent cells such as dendritic cells, B cells, cytotoxic CD8+ T, CD4+ T-helper, and NK cells in combination with cytokines, chemokines and other immune mediators are required for effective vaccines and immune reactions against cancer (Figure 1). Two anti-angiogenic vaccine approaches have shown promising results in reducing tumor growth and/or metastases: endothelial cell vaccines that demonstrate antitumor activity and vaccines targeting specific angiogenic targets. Figure 1

Major mechanistic immune pathways of anti-angiogenic vaccines and their targets. Vaccine antigens are processed by antigen processing cells such as dendritic cells and presented to T cells. Depending on the antigen, the route of administration, and the vector, peptide presentation to either major histocompatibility complex (MHC) class I or II occurs, with subsequent interaction with T-cell receptors on CD4+ or CD8+ cells. Cytotoxic CD8+ T cells recognize and lyse tumor endothelial cells directly by perforin-mediated and Fas-mediated cytotoxic mechanisms. CD4+ T-helper cells, through release of different cytokines, can induce Th1 or Th2 responses that stimulate B-cells to produce antibodies and/or activate NK cells and macrophages to inhibit tumor endothelium. Representative targets related to endothelial and cancer cells and their environment for anti-angiogenic vaccines are depicted. Reprinted with permission, Cleveland Clinic Center for Medical Art \& Photography (C) 2010. All Rights Reserved.

\section{Endothelial Cell Vaccines}

\section{Vaccines Expressing Defined Targets}

Defined endothelial vaccines are based on specific targets and include peptides and nucleic acids (DNA or RNA) that encode these peptides (see Table 1, Figure 2). Suitable angiogenic targets in tumors may be receptors/markers on endothelial cells or alternatively, may be growth factors secreted by cells other than endothelial cells. To date, there has been no target or epitope that is completely specific for tumor endothelial cells. For example, TEM8, one of the more specific tumor endothelial cell markers identified thus far, was originally found in the tumor vasculature and the developing embryo, but it has since been found on cell surfaces of melanomas, breast cancers, and dendritic cells. Despite the overlap in this system, we think that classification of angiogenic vaccines based on preponderance of their targets within most tumors may be useful. As a result, we have divided tumor endothelial vaccines with defined targets into three classes: 1) growth factors/receptors or epitopes that are primarily associated with growth of tumor endothelial cells; 2) growth factors/receptors or epitopes that promote growth of pericytes; and 3) proteins/growth factors/receptors that enhance both tumor and endothelial cell growth or survival. The growth factors were classified, not on their cells of origin, but on the location of their receptors.

\section{Figure 2}

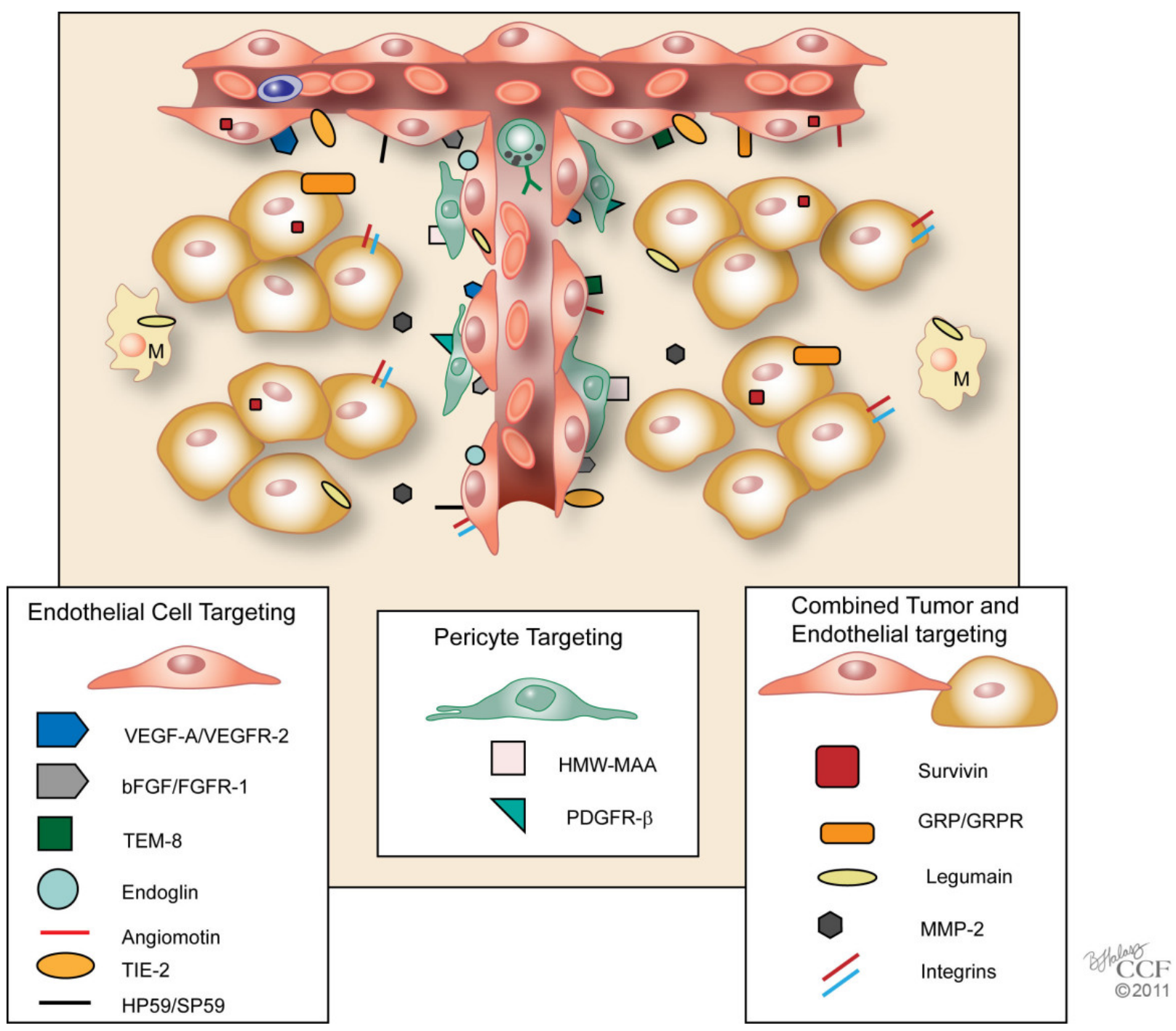


Tumor Endothelial Vaccines with Defined Targets. Schematic model of a tumor and its angiogenic vessels are shown with targets of tumor endothelial vaccines. These vaccines may be classified on their specific targets 1) that are primarily associated with tumor endothelial cells, 2) that promote growth of pericytes, or 3) that enhance both tumor and endothelial cell growth or survival. Growth factors were classified based on the location of their receptors. M, Macrophage. Reprinted with permission, Cleveland Clinic Center for Medical Art \& Photography (C) 2011. All Rights Reserved.

\section{Conclusion}

Significant resources including numerous pre-clinical and clinical studies have been devoted to the development of tumor vaccines. Thus far, these results have progressed and culminated in the approval a vaccine targeting advanced prostate cancer (Provenge). Although the benefits with this FDA-approved vaccine are modest, further improved vaccine versions are no doubt on the horizon and will aid with other vaccines approaches, including those against the tumor endothelium. Compared to tumor vaccines, the number of varied approaches for tumor endothelial vaccines is relatively limited and is currently restricted to pre-clinical experiments and primarily phase I trials.

As discussed in this review, several studies with tumor endothelial vaccines show anti-tumor efficacy in both transplantable and transgenic tumor-bearing animal models. Of particular note were the bacteria-based vaccines that showed marked antitumor response with varied anti-angiogenic genes and few if any side effects. Nevertheless, major obstacles still remain, including identification and validation of specific targets on the tumor endothelium, inhibition of local suppression mechanisms, and boosting anti-tumor immunity through NK cells [ 132]. Thus far, there have been few data from the endothelial vaccine studies on the various T-cell subtypes, including regulatory T-cells or myeloid derived suppressor cells [ 25, 133, 134], and comparison of T-cell subtypes in the tumor and peripheral tissues may be useful in development of more effective vaccines. Other immune cells such as NK cells have not yet shown a direct role in augmenting the efficacy of tumor endothelial vaccines [ 64, 87, 94, 130], but more research examining interactions among NK cells, dendritic cells, and immunomodulatory agents is needed [132, 135, 136].

Since tumor angiogenesis is a complex process, targeting a single epitope is unlikely to be successful. In many cases, the treated tumor adapts and finds alternative mechanisms of tumorigenesis eventually leading to resistance to therapy. Thus, combinations of anti-angiogenic vaccines with existing chemotherapy or immunomodulatory therapies offer interesting and exciting possibilities. For example, as discussed previously in this review, combinatory treatments between vaccines and IL-12, GM-CSF, CCL21, or $\beta$-defensins markedly increased the immune response toward tumor endothelial cells [ 39 , $41,62,64]$. Nevertheless, these co-stimulatory therapies have been used sparingly and other commonly used cytokines such as IL-2, IFN $\alpha$ or $\beta$ [ 137-139] have not been co-administered or transfected into immune and/or endothelial cells to augment vaccine efficacy. Moreover, considerable more research is needed to determine the optimal co-stimulatory therapy to be administered with the vaccine for the different delivery methods.

Another consideration in developing anti-angiogenic vaccines is their potential for causing complications. Cross-reactivity between tumor and non-tumor disease tissues due to tumor endothelial vac cine may result in reduced compensatory biological processes. The classic tumor endothelial target is VEGFR2 up-regulated not only in the endothelial vessels of tumors but also in healing wounds and hypoxic cardiac tissues. Interestingly, at least with 4 vaccine studies (VEGFR2, VEGF-A, bFGF, survivin/CCL21) tumor angiogenesis was markedly inhibited, but these vaccines did not interfere with normal physiologic processes in several studies $[32,35,47,76,77]$. The mechanism whereby tolerance to selfangiogenic antigens in tumors but not in normal angiogenic processes is broken remains unknown. It has been suggested that differences in breaking self-angiogenic antigen tolerance between tumors and normal physiological processes may be based on the difference of their vascular organization [ 32,140]; determining whether or not this is the mechanism for this difference will require further study.

To ensure effective tumor eradication and reduce autoimmune side effects, intensive efforts are still needed to identify additional targets specific to the tumor endothelium. One such study recently found highly specific and expressed markers of the tumor endothelium that were not expressed in quiescent blood vessels or physiologic angiogenesis [ 13].

Nevertheless, the efficacy of vaccines against these new markers has not yet been determined. Alternatively, finding tissuespecific vascular targets (e.g., prostate) may enable development of tumor endothelial vaccines with acceptable side effects $[141,142]$. There is also the possibility that tailored endothelial vaccines may be developed based on specific endothelial epitopes associated with certain tumors [ 143]. As new anti-angiogenic targets are discovered, we anticipate that promising new therapeutic approaches are on the horizon.

\section{Abbreviations}

- bFGF:

basic fibroblast growth factor

- CTL: cytotoxic T-lymphocyte

- DC: dendritic cells

- FGFR-1: fibroblast growth factor receptor-1 
- GRP:

gastrin-releasing peptide

- GM-CSF:

granulocyte macrophage-colony stimulating factor

- HMW-MAA:

High Molecular Weight-Melanoma Associated Antigen

- HUVECs:

human umbilical vein endothelial cells

- IFN:

interferon

- im:

intramuscular

- ip:

intraperioneal

- IL:

interleukin

- -LLO-HMW-MAA :

that contains and secretes a fragment of $H M W$-MAA fused to the $N$-terminal listeriolysin $O$

- MHC I:

Major Histocompatibility Complex I

- MMP-2:

Matrix Metalloproteinase-2

- NK:

Natural Killer cells

- PDGFR- $\beta$ :

platelet derived growth factor receptor beta

- TEM:

tumor endothelial marker

- Th:

Thelper

- VEGF:

vascular endothelial growth factor.

\section{Declarations}

\section{Acknowledgements}

The authors thank Drs. Pamela Talalay and Paul Anthony for their helpful suggestions and careful reading of this manuscript. This work was supported by the National Institutes of Health (R01-CA136938).

\section{Authors' original submitted files for images}

Below are the links to the authors' original submitted files for images.

Authors' original file for figure 1

Authors' original file for figure 2

\section{Competing interests}

The authors declare that they have no competing interests.

Authors' contributions

AM, QL, S-TC, and AJM were involved in preparation of the manuscript. AM and AJM also revised the manuscript for final approval. All authors have read and approved the final manuscript.

\section{References}

1. Rosen LS. Clinical experience with angiogenesis signaling inhibitors: focus on vascular endothelial growth factor (VEGF) blockers. Cancer Control. 2002;9:36-44.

View Article Google Scholar

2. Gordan JD Simon MC Hypoxia-inducible factors: central regulators of the tumor phenotype Curr Opin Genet Dev 20071771773215290

3. Gruber M, Simon MC. Hypoxia-inducible factors, hypoxia, and tumor angiogenesis. Curr Opin Hematol. 2006;13:169-174. 
4. Search for Clinical Trials-National Cancer Institute. [ http://www.cancer.gov/clinicaltrials/search]

5. Fens MH, Storm G, Schiffelers RM. Tumor vasculature as target for therapeutic intervention. Expert Opin Investig Drugs. 2010;19:1321-1338.

View Article Google Scholar

6. Tammela T, Zarkada G, Wallgard E, Murtomaki A, Suchting S, Wirzenius M, Waltari M, Hellstrom M, Schomber T, Peltonen R, et al. Blocking VEGFR-3 suppresses angiogenic sprouting and vascular network formation. Nature. 2008;454:656-660.

View Article Google Scholar

7. Hu B Cheng SY Angiopoietin-2: development of inhibitors for cancer therapy Curr Oncol Rep 200911 1111162867109

8. Chen QR, Zhang L, Gasper W, Mixson AJ. Targeting tumor angiogenesis with gene therapy. Mol Genet Metab. 2001;74:120-127.

View Article Google Scholar

9. Cao Y. Off-tumor target--beneficial site for antiangiogenic cancer therapy?. Nat Rev Clin Oncol. 2010;7:604608.

View Article Google Scholar

10. Cao Y. Angiogenesis: What can it offer for future medicine?. Exp Cell Res. 2010;316:1304-1308.

View Article Google Scholar

11. Cao Y, Langer R. Optimizing the delivery of cancer drugs that block angiogenesis. Sci Transl Med. 2010;2:15ps13-.

View Article Google Scholar

12. St Croix B, Rago C, Velculescu V, Traverso G, Romans KE, Montgomery E, Lal A, Riggins GJ, Lengauer C, Vogelstein B, Kinzler KW. Genes expressed in human tumor endothelium. Science. 2000;289:1197-1202. View Article Google Scholar

13. Seaman S Stevens J Yang MY Logsdon D Graff-Cherry C St Croix B Genes that distinguish physiological and pathological angiogenesis Cancer Cell 2007115395542039723

14. Boehm T, Folkman J, Browder T, O'Reilly MS. Antiangiogenic therapy of experimental cancer does not induce acquired drug resistance. Nature. 1997;390:404-407.

View Article Google Scholar

15. Huang J, Soffer SZ, Kim ES, McCrudden KW, New T, Manley CA, Middlesworth W, O'Toole K, Yamashiro DJ, Kandel JJ. Vascular remodeling marks tumors that recur during chronic suppression of angiogenesis. Mol Cancer Res. 2004;2:36-42.

View Article Google Scholar

16. Hida K, Hida Y, Amin DN, Flint AF, Panigrahy D, Morton CC, Klagsbrun M. Tumor-associated endothelial cells with cytogenetic abnormalities. Cancer Res. 2004;64:8249-8255.

View Article Google Scholar

17. Hida K, Klagsbrun M. A new perspective on tumor endothelial cells: unexpected chromosome and centrosome abnormalities. Cancer Res. 2005;65:2507-2510.

View Article Google Scholar

18. Ricci-Vitiani L, Pallini R, Biffoni M, Todaro M, Invernici G, Cenci T, Maira G, Parati EA, Stassi G, Larocca LM, De Maria R. Tumour vascularization via endothelial differentiation of glioblastoma stem-like cells. Nature. 2010;468:824-828.

View Article Google Scholar

19. Wang R, Chadalavada K, Wilshire J, Kowalik U, Hovinga KE, Geber A, Fligelman B, Leversha M, Brennan C, Tabar V. Glioblastoma stem-like cells give rise to tumour endothelium. Nature. 2010;468:829-833. View Article Google Scholar

20. Folkman J. Fighting cancer by attacking its blood supply. Sci Am. 1996;275:150-154. 
21. Folkman J. Antiangiogenic Therapy. Principles and Practice of Oncology. 1997;:3075-3085.

View Article Google Scholar

22. Hurwitz H. Integrating the anti-VEGF-A humanized monoclonal antibody bevacizumab with chemotherapy in advanced colorectal cancer. Clin Colorectal Cancer. 2004;4:S62-68.

View Article Google Scholar

23. Eskens FA, Sleijfer S. The use of bevacizumab in colorectal, lung, breast, renal and ovarian cancer: where does it fit?. Eur J Cancer. 2008;44:2350-2356.

View Article Google Scholar

24. Grothey A, Ellis LM. Targeting angiogenesis driven by vascular endothelial growth factors using antibodybased therapies. Cancer J. 2008;14:170-177.

View Article Google Scholar

25. Chaudhuri D, Suriano R, Mittelman A, Tiwari RK. Targeting the immune system in cancer. Curr Pharm Biotechnol. 2009;10:166-184.

View Article Google Scholar

26. Palena C Schlom J Vaccines against human carcinomas: strategies to improve antitumor immune responses J Biomed Biotechnol 201020103806972840411

27. Fioretti D Iurescia S Fazio VM Rinaldi M DNA vaccines: developing new strategies against cancer J Biomed Biotechnol 201020101743782846346

28. Chiang CL Benencia F Coukos G Whole tumor antigen vaccines Semin Immunol 201022132 1433119500

29. Signori E, Iurescia S, Massi E, Fioretti D, Chiarella P, De Robertis M, Rinaldi M, Tonon G, Fazio VM. DNA vaccination strategies for anti-tumour effective gene therapy protocols. Cancer Immunol Immunother. 2010;59:1583-1591.

View Article Google Scholar

30. Reisfeld RA, Niethammer AG, Luo Y, Xiang R. DNA vaccines designed to inhibit tumor growth by suppression of angiogenesis. Int Arch Allergy Immunol. 2004;133:295-304.

View Article Google Scholar

31. Gravekamp C, Paterson Y. Harnessing Listeria monocytogenes to target tumors. Cancer Biol Ther. 2010;9:257265.

View Article Google Scholar

32. Seavey MM Maciag PC Al-Rawi N Sewell D Paterson Y An anti-vascular endothelial growth factor receptor 2/fetal liver kinase-1 Listeria monocytogenes anti-angiogenesis cancer vaccine for the treatment of primary and metastatic Her-2/neu+ breast tumors in a mouse model J Immunol 20091825537 55462850569

33. Maciag PC Seavey MM Pan ZK Ferrone S Paterson Y Cancer immunotherapy targeting the high molecular weight melanoma-associated antigen protein results in a broad antitumor response and reduction of pericytes in the tumor vasculature Cancer Res 200868806680753004011

34. Kaplan CD, Kruger JA, Zhou H, Luo Y, Xiang R, Reisfeld RA. A novel DNA vaccine encoding PDGFRbeta suppresses growth and dissemination of murine colon, lung and breast carcinoma. Vaccine. 2006;24:69947002.

View Article Google Scholar

35. Xiang R, Mizutani N, Luo Y, Chiodoni C, Zhou H, Mizutani M, Ba Y, Becker JC, Reisfeld RA. A DNA vaccine targeting survivin combines apoptosis with suppression of angiogenesis in lung tumor eradication. Cancer Res. 2005;65:553-561.

View Article Google Scholar

36. Daudel D, Weidinger G, Spreng S. Use of attenuated bacteria as delivery vectors for DNA vaccines. Expert Rev Vaccines. 2007;6:97-110

View Article Google Scholar 
37. Lladser A, Ljungberg K, Tufvesson H, Tazzari M, Roos AK, Quest AF, Kiessling R. Intradermal DNA electroporation induces survivin-specific CTLs, suppresses angiogenesis and confers protection against mouse melanoma. Cancer Immunol Immunother. 2010;59:81-92.

$\underline{\text { View Article }}$ Google Scholar

38. Holmgren L Ambrosino E Birot O Tullus C Veitonmaki N Levchenko T Carlson LM Musiani P Iezzi M Curcio C A DNA vaccine targeting angiomotin inhibits angiogenesis and suppresses tumor growth Proc Natl Acad Sci USA 2006103920892131482591

39. Lladser A, Parraga M, Quevedo L, Carmen Molina M, Silva S, Ferreira A, Billetta R, AF GQ. Naked DNA immunization as an approach to target the generic tumor antigen survivin induces humoral and cellular immune responses in mice. Immunobiology. 2006;211:11-27.

View Article Google Scholar

40. Zhu K, Qin H, Cha SC, Neelapu SS, Overwijk W, Lizee GA, Abbruzzese JL, Hwu P, Radvanyi L, Kwak LW, Chang DZ. Survivin DNA vaccine generated specific antitumor effects in pancreatic carcinoma and lymphoma mouse models. Vaccine. 2007;25:7955-7961.

View Article Google Scholar

41. Nanni P Nicoletti G De Giovanni C Landuzzi L Di Carlo E Cavallo F Pupa SM Rossi I Colombo MP Ricci C Combined allogeneic tumor cell vaccination and systemic interleukin 12 prevents mammary carcinogenesis in HER-2/neu transgenic mice J Exp Med 2001194119512052195980

42. Hu B, Wei Y, Tian L, Zhao X, Lu Y, Wu Y, Yao B, Liu J, Niu T, Wen Y, et al. Active antitumor immunity elicited by vaccine based on recombinant form of epidermal growth factor receptor. J Immunother. 2005;28:236-244. $\underline{\text { View Article Google Scholar }}$

43. Wada S, Tsunoda T, Baba T, Primus FJ, Kuwano H, Shibuya M, Tahara H. Rationale for antiangiogenic cancer therapy with vaccination using epitope peptides derived from human vascular endothelial growth factor receptor 2. Cancer Res. 2005;65:4939-4946.

View Article Google Scholar

44. Tacken PJ, de Vries IJM, Torensma R, Figdor CG. Dendritic-cell immunotherapy: from ex vivo loading to in vivo targeting. Nature Reviews Immunology. 2007;7:790-802.

View Article Google Scholar

45. Li Y Wang MN Li H King KD Bassi R Sun H Santiago A Hooper AT Bohlen P Hicklin DJ Active immunization against the vascular endothelial growth factor receptor flk1 inhibits tumor angiogenesis and metastasis J Exp Med 2002195157515842193561

46. Nair SK Morse M Boczkowski D Cumming RI Vasovic L Gilboa E Lyerly HK Induction of tumor-specific cytotoxic T lymphocytes in cancer patients by autologous tumor RNA-Transfected dendritic cells Annals of Surgery 20022355405491422470

47. Nair S, Boczkowski D, Moeller B, Dewhirst M, Vieweg J, Gilboa E. Synergy between tumor immunotherapy and antiangiogenic therapy. Blood. 2003;102:964-971.

View Article Google Scholar

48. Pellegatta S Poliani PL Stucchi E Corno D Colombo CA Orzan F Ravanini M Finocchiaro G Intra-tumoral dendritic cells increase efficacy of peripheral vaccination by modulation of glioma microenvironment Neuro Oncol 2010123773882940598

49. Lai MD Yen MC Lin CM Tu CF Wang CC Lin PS Yang HJ Lin CC The effects of DNA formulation and administration route on cancer therapeutic efficacy with xenogenic EGFR DNA vaccine in a lung cancer animal model Genet Vaccines Ther 2009722645394

50. Wei YQ, Wang QR, Zhao X, Yang L, Tian L, Lu Y, Kang B, Lu CJ, Huang MJ, Lou YY, et al. Immunotherapy of tumors with xenogeneic endothelial cells as a vaccine. Nat Med. 2000;6:1160-1166.

View Article Google Scholar

51. Okaji Y, Tsuno NH, Kitayama J, Saito S, Takahashi T, Kawai K, Yazawa K, Asakage M, Hori N, Watanabe T, et al. Vaccination with autologous endothelium inhibits angiogenesis and metastasis of colon cancer through autoimmunity. Cancer Science. 2004;95:85-90.

View Article Google Scholar 
52. Scappaticci FA, Nolan GP. Induction of anti-tumor immunity in mice using a syngeneic endothelial cell vaccine. Anticancer Res. 2003;23:1165-1172.

View Article Google Scholar

53. Yoshiura K, Nishishita T, Nakaoka T, Yamashita N, Yamashita N. Inhibition of B16 melanoma growth and metastasis in C57BL mice by vaccination with a syngeneic endothelial cell line. Journal of Experimental \& Clinical Cancer Research. 2009;28:13-.

View Article Google Scholar

54. Okaji Y, Tsuno NH, Tanaka M, Yoneyama S, Matsuhashi M, Kitayama J, Saito S, Nagura Y, Tsuchiya T, Yamada J, et al. Pilot study of anti-angiogenic vaccine using fixed whole endothelium in patients with progressive malignancy after failure of conventional therapy. European Journal of Cancer. 2008;44:383-390.

View Article Google Scholar

55. Zhang W, Liu JN, Tan XY. Vaccination with xenogeneic tumor endothelial proteins isolated in situ inhibits tumor angiogenesis and spontaneous metastasis. Int J Cancer. 2009;125:124-132.

$\underline{\text { View Article Google Scholar }}$

56. Shalaby F, Rossant J, Yamaguchi TP, Gertsenstein M, Wu XF, Breitman ML, Schuh AC. Failure of blood-island formation and vasculogenesis in Flk-1-deficient mice. Nature. 1995;376:62-66.

View Article Google Scholar

57. Taraboletti G, Margosio B. Antiangiogenic and antivascular therapy for cancer. Curr Opin Pharmacol. 2001;1:378-384.

View Article Google Scholar

58. Wei YQ Huang MJ Yang L Zhao X Tian L Lu Y Shu JM Lu CJ Niu T Kang B Immunogene therapy of tumors with vaccine based on Xenopus homologous vascular endothelial growth factor as a model antigen Proc Natl Acad Sci USA 200198115451155058766

59. Niethammer AG, Xiang R, Becker JC, Wodrich H, Pertl U, Karsten G, Eliceiri BP, Reisfeld RA. A DNA vaccine against VEGF receptor 2 prevents effective angiogenesis and inhibits tumor growth. Nat Med. 2002;8:13691375 .

View Article Google Scholar

60. Hou JM, Liu JY, Yang L, Zhao X, Tian L, Ding ZY, Wen YJ, Niu T, Xiao F, Lou YY, et al. Combination of lowdose gemcitabine and recombinant quail vascular endothelial growth factor receptor-2 as a vaccine induces synergistic antitumor activities. Oncology. 2005;69:81-87.

$\underline{\text { View Article }}$ Google Scholar

61. Zhou H, Luo Y, Mizutani M, Mizutani N, Reisfeld RA, Xiang R. T cell-mediated suppression of angiogenesis results in tumor protective immunity. Blood. 2005; 106:2026-2032.

View Article Google Scholar

62. Dong Y, Qian J, Ibrahim R, Berzofsky JA, Khleif SN. Identification of H-2Db-specific CD8+ T-cell epitopes from mouse VEGFR2 that can inhibit angiogenesis and tumor growth. J Immunother. 2006;29:32-40.

View Article Google Scholar

63. Luo Y Markowitz D Xiang R Zhou H Reisfeld RA FLK-1-based minigene vaccines induce T cellmediated suppression of angiogenesis and tumor protective immunity in syngeneic BALB/c mice Vaccine 200725140914151995657

64. Wang YS, Wang GQ, Wen YJ, Wang L, Chen XC, Chen P, Kan B, Li J, Huang C, Lu Y, et al. Immunity against tumor angiogenesis induced by a fusion vaccine with murine beta-defensin 2 and mFlk-1. Clin Cancer Res. 2007;13:6779-6787.

View Article Google Scholar

65. Xie K Bai RZ Wu Y Liu Q Liu K Wei YQ Anti-tumor effects of a human VEGFR-2-based DNA vaccine in mouse models Genet Vaccines Ther 20097103224891

66. Miyazawa M, Ohsawa R, Tsunoda T, Hirono S, Kawai M, Tani M, Nakamura Y, Yamaue H. Phase I clinical trial using peptide vaccine for human vascular endothelial growth factor receptor 2 in combination with gemcitabine for patients with advanced pancreatic cancer. Cancer Sci. 2010;101:433-439.

View Article Google Scholar 
67. Zuo SG, Chen Y, Wu ZP, Liu X, Liu C, Zhou YC, Wu CL, Jin CG, Gu YL, Li J, et al. Orally administered DNA vaccine delivery by attenuated Salmonella typhimurium targeting fetal liver kinase 1 inhibits murine Lewis lung carcinoma growth and metastasis. Biol Pharm Bull. 2010;33:174-182.

View Article Google Scholar

68. Yang D, Chertov O, Bykovskaia SN, Chen Q, Buffo MJ, Shogan J, Anderson M, Schroder JM, Wang JM, Howard OM, Oppenheim JJ. Beta-defensins: linking innate and adaptive immunity through dendritic and T cell CCR6. Science. 1999;286:525-528.

View Article Google Scholar

69. Biragyn A, Ruffini PA, Leifer CA, Klyushnenkova E, Shakhov A, Chertov O, Shirakawa AK, Farber JM, Segal DM, Oppenheim JJ, Kwak LW. Toll-like receptor 4-dependent activation of dendritic cells by beta-defensin 2 . Science. 2002;298:1025-1029.

View Article Google Scholar

70. Lee YH, Tokunaga T, Oshika Y, Suto R, Yanagisawa K, Tomisawa M, Fukuda H, Nakano H, Abe S, Tateishi A, et al. Cell-retained isoforms of vascular endothelial growth factor (VEGF) are correlated with poor prognosis in osteosarcoma. Eur J Cancer. 1999;35:1089-1093.

$\underline{\text { View Article } \text { Google Scholar }}$

71. Oshika Y, Nakamura M, Tokunaga T, Ozeki Y, Fukushima Y, Hatanaka H, Abe Y, Yamazaki H, Kijima H, Tamaoki N, Ueyama Y. Expression of cell-associated isoform of vascular endothelial growth factor 189 and its prognostic relevance in non-small cell lung cancer. Int J Oncol. 1998;12:541-544.

View Article Google Scholar

72. Li XH, Tang L, Liu D, Sun HM, Zhou CC, Tan LS, Wang LP, Zhang PD, Zhang SQ. [Antitumor effect of recombinant $\mathrm{T} 7$ phage vaccine expressing xenogenic vascular endothelial growth factor on Lewis lung cancer in mice]. Ai Zheng. 2006;25:1221-1226.

View Article Google Scholar

73. Rad FH Le Buanec H Paturance S Larcier P Genne P Ryffel B Bensussan A Bizzini B Gallo RC Zagury D Uzan G VEGF kinoid vaccine, a therapeutic approach against tumor angiogenesis and metastases Proc Natl Acad Sci USA 2007104283728421797624

74. Harper SJ Bates DO VEGF-A splicing: the key to anti-angiogenic therapeutics? Nat Rev Cancer 20088 8808872613352

75. Varey AH Rennel ES Qiu Y Bevan HS Perrin RM Raffy S Dixon AR Paraskeva C Zaccheo O Hassan AB VEGF $165 \mathrm{~b}$, an antiangiogenic VEGF-A isoform, binds and inhibits bevacizumab treatment in experimental colorectal carcinoma: balance of pro- and antiangiogenic VEGF-A isoforms has implications for therapy Br J Cancer 200898136613792361696

76. Plum SM, Holaday JW, Ruiz A, Madsen JW, Fogler WE, Fortier AH. Administration of a liposomal FGF-2 peptide vaccine leads to abrogation of FGF-2-mediated angiogenesis and tumor development. Vaccine. 2000;19:1294-1303.

View Article Google Scholar

77. Plum SM, Vu HA, Mercer B, Fogler WE, Fortier AH. Generation of a specific immunological response to FGF-2 does not affect wound healing or reproduction. Immunopharmacol Immunotoxicol. 2004;26:29-41. View Article Google Scholar

78. He QM, Wei YQ, Tian L, Zhao X, Su JM, Yang L, Lu Y, Kan B, Lou YY, Huang MJ, et al. Inhibition of tumor growth with a vaccine based on xenogeneic homologous fibroblast growth factor receptor-1 in mice. J Biol Chem. 2003;278:21831-21836.

View Article Google Scholar

79. Nanda A, Carson-Walter EB, Seaman S, Barber TD, Stampfl J, Singh S, Vogelstein B, Kinzler KW, St Croix B. TEM8 interacts with the cleaved C5 domain of collagen alpha 3(VI). Cancer Res. 2004;64:817-820.

View Article Google Scholar

80. Carson-Walter EB, Watkins DN, Nanda A, Vogelstein B, Kinzler KW, St Croix B. Cell surface tumor endothelial markers are conserved in mice and humans. Cancer Res. 2001;61:6649-6655.

$\underline{\text { View Article }}$ Google Scholar 
81. Venanzi FM, Petrini M, Fiammenghi L, Bolli E, Granato AM, Ridolfi L, Gabrielli F, Barucca A, Concetti A, Ridolfi R, Riccobon A. Tumor endothelial marker 8 expression levels in dendritic cell-based cancer vaccines are related to clinical outcome. Cancer Immunol Immunother. 2010;59:27-34.

View Article Google Scholar

82. Felicetti P, Mennecozzi M, Barucca A, Montgomery S, Orlandi F, Manova K, Houghton AN, Gregor PD, Concetti A, Venanzi FM. Tumor endothelial marker 8 enhances tumor immunity in conjunction with immunization against differentiation Ag. Cytotherapy. 2007;9:23-34.

View Article Google Scholar

83. Ruan Z, Yang Z, Wang Y, Wang H, Chen Y, Shang X, Yang C, Guo S, Han J, Liang H, Wu Y. DNA vaccine against tumor endothelial marker 8 inhibits tumor angiogenesis and growth. J Immunother. 2009;32:486-491. $\underline{\text { View Article Google Scholar }}$

84. Dales JP, Garcia S, Andrac L, Carpentier S, Ramuz O, Lavaut MN, Allasia C, Bonnier P, Charpin C. Prognostic significance of angiogenesis evaluated by CD105 expression compared to CD31 in 905 breast carcinomas: correlation with long-term patient outcome. Int J Oncol. 2004;24:1197-1204.

$\underline{\text { View Article Google Scholar }}$

85. Takahashi N, Kawanishi-Tabata R, Haba A, Tabata M, Haruta Y, Tsai H, Seon BK. Association of serum endoglin with metastasis in patients with colorectal, breast, and other solid tumors, and suppressive effect of chemotherapy on the serum endoglin. Clin Cancer Res. 2001;7:524-532.

View Article Google Scholar

86. Hofmeister V, Schrama D, Becker JC. Anti-cancer therapies targeting the tumor stroma. Cancer Immunol Immunother. 2008;57:1-17.

View Article Google Scholar

87. Tan GH, Wei YQ, Tian L, Zhao X, Yang L, Li J, He QM, Wu Y, Wen YJ, Yi T, et al. Active immunotherapy of tumors with a recombinant xenogeneic endoglin as a model antigen. Eur J Immunol. 2004;34:2012-2021.

View Article Google Scholar

88. Tan GH, Tian L, Wei YQ, Zhao X, Li J, Wu Y, Wen YJ, Yi T, Ding ZY, Kan B, et al. Combination of low-dose cisplatin and recombinant xenogeneic endoglin as a vaccine induces synergistic antitumor activities. Int $\mathrm{J}$ Cancer. 2004;112:701-706.

View Article Google Scholar

89. Troyanovsky B Levchenko T Mansson G Matvijenko O Holmgren L Angiomotin: an angiostatin binding protein that regulates endothelial cell migration and tube formation J Cell Biol 20011521247 12542199208

90. Bratt A, Birot O, Sinha I, Veitonmaki N, Aase K, Ernkvist M, Holmgren L. Angiomotin regulates endothelial cell-cell junctions and cell motility. J Biol Chem. 2005;280:34859-34869.

$\underline{\text { View Article Google Scholar }}$

91. Jiang WG Watkins G Douglas-Jones A Holmgren L Mansel RE Angiomotin and angiomotin like proteins, their expression and correlation with angiogenesis and clinical outcome in human breast cancer BMC Cancer 20066161386688

92. Peters KG Coogan A Berry D Marks J Iglehart JD Kontos CD Rao P Sankar S Trogan E Expression of Tie2/Tek in breast tumour vasculature provides a new marker for evaluation of tumour angiogenesis Br J Cancer 19987751562151265

93. Lin P Buxton JA Acheson A Radziejewski C Maisonpierre PC Yancopoulos GD Channon KM Hale LP Dewhirst MW George SE Peters KG Antiangiogenic gene therapy targeting the endothelium-specific receptor tyrosine kinase Tie2 Proc Natl Acad Sci USA 1998958829883421162

94. Luo Y, Wen YJ, Ding ZY, Fu CH, Wu Y, Liu JY, Li Q, He QM, Zhao X, Jiang Y, et al. Immunotherapy of tumors with protein vaccine based on chicken homologous Tie-2. Clin Cancer Res. 2006;12:1813-1819.

View Article Google Scholar

95. Ramage JM, Metheringham R, Conn A, Spendlove I, Moss RS, Patton DT, Murray JC, Rees RC, Durrant LG. Identification of an HLA-A*0201 cytotoxic T lymphocyte epitope specific to the endothelial antigen Tie2. Int J Cancer. 2004;110:245-250.

View Article Google Scholar 
96. Fu C, Bardhan S, Cetateanu ND, Wamil BD, Wang Y, Yan HP, Shi E, Carter C, Venkov C, Yakes FM, et al. Identification of a novel membrane protein, HP59, with therapeutic potential as a target of tumor angiogenesis. Clin Cancer Res. 2001;7:4182-4194.

$\underline{\text { View Article }}$ Google Scholar

97. Rojas J, Green RS, Hellerqvist CG, Olegard R, Brigham KL, Stahlman MT. Studies on group B beta-hemolytic Streptococcus. II. Effects on pulmonary hemodynamics and vascular permeability in unanesthetized sheep. Pediatr Res. 1981;15:899-904.

View Article Google Scholar

98. Sundell HW, Yan H, Carter CE, Wamil BD, Wu K, Gaddipati R, Li D, Hellerqvist CG. Isolation and identification of the group B streptococcal toxin CM101 from infants with sepsis. J Pediatr. 2000;137:338-344.

View Article Google Scholar

99. Funa K, Uramoto H. Regulatory mechanisms for the expression and activity of platelet-derived growth factor receptor. Acta Biochim Pol. 2003;50:647-658.

View Article Google Scholar

100. Ostman A. PDGF receptors-mediators of autocrine tumor growth and regulators of tumor vasculature and stroma. Cytokine Growth Factor Rev. 2004;15:275-286.

$\underline{\text { View Article } \text { Google Scholar }}$

101. Song S Ewald AJ Stallcup W Werb Z Bergers G PDGFRbeta+ perivascular progenitor cells in tumours regulate pericyte differentiation and vascular survival Nat Cell Biol 200578708792771163

102. Fest S, Huebener N, Bleeke M, Durmus T, Stermann A, Woehler A, Baykan B, Zenclussen AC, Michalsky E, Jaeger IS, et al. Survivin minigene DNA vaccination is effective against neuroblastoma. Int J Cancer. 2009;125:104-114.

View Article Google Scholar

103. Hajri A, Balboni G, Koenig M, Garaud JC, Damge C. Gastrin-releasing peptide: in vivo and in vitro growth effects on an acinar pancreatic carcinoma. Cancer Res. 1992;52:3726-3732.

View Article Google Scholar

104. Lango MN, Dyer KF, Lui VW, Gooding WE, Gubish C, Siegfried JM, Grandis JR. Gastrin-releasing peptide receptor-mediated autocrine growth in squamous cell carcinoma of the head and neck. J Natl Cancer Inst. 2002;94:375-383.

View Article Google Scholar

105. Kim S Hu W Kelly DR Hellmich MR Evers BM Chung DH Gastrin-releasing peptide is a growth factor for human neuroblastomas Ann Surg 20022356216291422487

106. Cuttitta F, Carney DN, Mulshine J, Moody TW, Fedorko J, Fischler A, Minna JD. Bombesin-like peptides can function as autocrine growth factors in human small-cell lung cancer. Nature. 1985;316:823-826.

View Article Google Scholar

107. Carney DN, Cuttitta F, Moody TW, Minna JD. Selective stimulation of small cell lung cancer clonal growth by bombesin and gastrin-releasing peptide. Cancer Res. 1987;47:821-825.

View Article Google Scholar

108. Yano T, Pinski J, Groot K, Schally AV. Stimulation by bombesin and inhibition by bombesin/gastrin-releasing peptide antagonist RC-3095 of growth of human breast cancer cell lines. Cancer Res. 1992;52:4545-4547.

View Article Google Scholar

109. Vangsted AJ, Andersen EV, Nedergaard L, Zeuthen J. Gastrin releasing peptide GRP(14-27) in human breast cancer cells and in small cell lung cancer. Breast Cancer Res Treat. 1991;19:119-128.

View Article Google Scholar

110. Scott N Millward E Cartwright EJ Preston SR Coletta PL Gastrin releasing peptide and gastrin releasing peptide receptor expression in gastrointestinal carcinoid tumours J Clin Pathol 2004571891921770197

111. Martinez A, Zudaire E, Julian M, Moody TW, Cuttitta F. Gastrin-releasing peptide (GRP) induces angiogenesis and the specific GRP blocker 77427 inhibits tumor growth in vitro and in vivo. Oncogene. 2005;24:41064113. 
112. Levine L, Lucci JA, Pazdrak B, Cheng JZ, Guo YS, Townsend CM, Hellmich MR. Bombesin stimulates nuclear factor kappa B activation and expression of proangiogenic factors in prostate cancer cells. Cancer Res. 2003;63:3495-3502.

View Article Google Scholar

113. Kang J Ishola TA Baregamian N Mourot JM Rychahou PG Evers BM Chung DH Bombesin induces angiogenesis and neuroblastoma growth Cancer Lett 20072532732812709810

114. Cornelio DB, Roesler R, Schwartsmann G. Gastrin-releasing peptide receptor as a molecular target in experimental anticancer therapy. Ann Oncol. 2007;18:1457-1466.

View Article Google Scholar

115. Guojun W, Wei G, Kedong O, Yi H, Yanfei X, Qingmei C, Yankai Z, Jie W, Hao F, Taiming L, et al. A novel vaccine targeting gastrin-releasing peptide: efficient inhibition of breast cancer growth in vivo. Endocr Relat Cancer. 2008;15:149-159.

$\underline{\text { View Article }}$ Google Scholar

116. Fang J Lu Y Ouyang K Wu G Zhang H Liu Y Chen Y Lin M Wang H Jin L Specific antibodies elicited by a novel DNA vaccine targeting gastrin-releasing peptide inhibit murine melanoma growth in vivo Clin Vaccine Immunol 200916103310392708394

117. Liu C, Sun C, Huang H, Janda K, Edgington T. Overexpression of legumain in tumors is significant for invasion/metastasis and a candidate enzymatic target for prodrug therapy. Cancer Res. 2003;63:2957-2964. View Article Google Scholar

118. Murthy RV, Arbman G, Gao J, Roodman GD, Sun XF. Legumain expression in relation to clinicopathologic and biological variables in colorectal cancer. Clin Cancer Res. 2005;11:2293-2299.

View Article Google Scholar

119. Luo Y Zhou H Krueger J Kaplan C Lee SH Dolman C Markowitz D Wu W Liu C Reisfeld RA Xiang R Targeting tumor-associated macrophages as a novel strategy against breast cancer J Clin Invest 2006116 213221411513049

120. Lewen S, Zhou H, Hu HD, Cheng T, Markowitz D, Reisfeld RA, Xiang R, Luo Y. A Legumain-based minigene vaccine targets the tumor stroma and suppresses breast cancer growth and angiogenesis. Cancer Immunol Immunother. 2008;57:507-515.

View Article Google Scholar

121. Rasmussen HS, McCann PP. Matrix metalloproteinase inhibition as a novel anticancer strategy: a review with special focus on batimastat and marimastat. Pharmacol Ther. 1997;75:69-75.

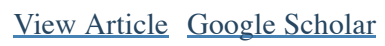

122. Anderson IC, Shipp MA, Docherty AP, Teicher BA. Combination therapy including a gelatinase inhibitor and cytoxic agent reduces local invasion and metastasis of murine Lewis lung carcinoma. Cancer Research. 1996;56:715-718.

$\underline{\text { View Article } \text { Google Scholar }}$

123. Su JM, Wei YQ, Tian L, Zhao X, Yang L, He QM, Wang Y, Lu Y, Wu Y, Liu F, et al. Active immunogene therapy of cancer with vaccine on the basis of chicken homologous matrix metalloproteinase-2. Cancer Res. 2003;63:600-607.

$\underline{\text { View Article Google Scholar }}$

124. Smyth E. The Trouble with Inhibitors. Signalling scissors: new perspectives on proteases; Brescia, Italy. $2003 ;:-$. View Article Google Scholar

125. Dove A. MMP inhibitors: glimmers of hope amidst clinical failures. Nat Med. 2002;8:95-. View Article Google Scholar

126. Overall CM Kleifeld O Towards third generation matrix metalloproteinase inhibitors for cancer therapy $\mathrm{Br}$ J Cancer 2006949419462361222

127. Overall CM, Kleifeld O. Tumour microenvironment - opinion: validating matrix metalloproteinases as drug targets and anti-targets for cancer therapy. Nat Rev Cancer. 2006;6:227-239. 
128. Eskens FA, Dumez H, Hoekstra R, Perschl A, Brindley C, Bottcher S, Wynendaele W, Drevs J, Verweij J, van Oosterom AT. Phase I and pharmacokinetic study of continuous twice weekly intravenous administration of Cilengitide (EMD 121974), a novel inhibitor of the integrins alphavbeta3 and alphavbeta5 in patients with advanced solid tumours. Eur J Cancer. 2003;39:917-926.

View Article Google Scholar

129. Lou YY, Wei YQ, Yang L, Zhao X, Tian L, Lu Y, Wen YJ, Liu F, Huang MJ, Kang B, et al. Immunogene therapy of tumors with a vaccine based on the ligand-binding domain of chicken homologous integrin beta3. Immunol Invest. 2002;31:51-69.

View Article Google Scholar

130. Liu JY, Wei YQ, Yang L, Zhao X, Tian L, Hou JM, Niu T, Liu F, Jiang Y, Hu B, et al. Immunotherapy of tumors with vaccine based on quail homologous vascular endothelial growth factor receptor-2. Blood. 2003;102:1815-1823.

View Article Google Scholar

131. Dirix LY Van Dam PA Prove PA Vermeulen PB Bevacizumab in the Treatment of Patients with Advanced Breast Cancer: Where have We Landed? Ther Adv Med Oncol 201023313423126024

132. Bielawska-Pohl A, Crola C, Caignard A, Gaudin C, Dus D, Kieda C, Chouaib S. Human NK cells lyse organspecific endothelial cells: analysis of adhesion and cytotoxic mechanisms. J Immunol. 2005; 174:5573-5582. View Article Google Scholar

133. Tsuji K, Hamada T, Uenaka A, Wada H, Sato E, Isobe M, Asagoe K, Yamasaki O, Shiku H, Ritter G, et al. Induction of immune response against NY-ESO-1 by CHP-NY-ESO-1 vaccination and immune regulation in a melanoma patient. Cancer Immunol Immunother. 2008;57:1429-1437.

View Article Google Scholar

134. Ostrand-Rosenberg S Myeloid-derived suppressor cells: more mechanisms for inhibiting antitumor immunity Cancer Immunol Immunother 201059159316003706261

135. Bielawska-Pohl A, Blesson S, Benlalam H, Trenado A, Opolon P, Bawa O, Rouffiac V, Dus D, Kieda C, Chouaib S. The anti-angiogenic activity of IL-12 is increased in iNOS-/- mice and involves NK cells. J Mol Med. 2010;88:775-784

View Article Google Scholar

136. Osada T, Clay T, Hobeika A, Lyerly HK, Morse MA. NK cell activation by dendritic cell vaccine: a mechanism of action for clinical activity. Cancer Immunol Immunother. 2006;55:1122-1131.

View Article Google Scholar

137. Sidky YA, Borden EC. Inhibition of angiogenesis by interferons: effects on tumor- and lymphocyte-induced vascular responses. Cancer Res. 1987;47:5155-5161.

View Article Google Scholar

138. Majewski S, Szmurlo A, Marczak M, Jablonska S, Bollag W. Synergistic effect of retinoids and interferon alpha on tumor-induced angiogenesis: anti-angiogenic effect on HPV-harboring tumor-cell lines. Int J Cancer. 1994;57:81-85.

View Article Google Scholar

139. Slaton JW, Perrotte P, Inoue K, Dinney CP, Fidler IJ. Interferon-alpha-mediated down-regulation of angiogenesis-related genes and therapy of bladder cancer are dependent on optimization of biological dose and schedule. Clin Cancer Res. 1999;5:2726-2734.

View Article Google Scholar

140. Benlalam H, Jalil A, Hasmim M, Pang B, Tamouza R, Mitterrand M, Godet Y, Lamerant N, Robert C, Avril MF, et al. Gap junction communication between autologous endothelial and tumor cells induce cross-recognition and elimination by specific CTL. J Immunol. 2009;182:2654-2664.

View Article Google Scholar

141. Arap W Haedicke W Bernasconi M Kain R Rajotte D Krajewski S Ellerby HM Bredesen DE Pasqualini R Ruoslahti E Targeting the prostate for destruction through a vascular address Proc Natl Acad Sci USA 20029915271531122224 
142. Trepel M, Arap W, Pasqualini R. In vivo phage display and vascular heterogeneity: implications for targeted medicine. Curr Opin Chem Biol. 2002;6:399-404.

View Article Google Scholar

143. Ruoslahti E, Duza T, Zhang L. Vascular homing peptides with cell-penetrating properties. Curr Pharm Des. 2005;11:3655-3660.

View Article Google Scholar 